\title{
Chapter 7 \\ Transitions and Adjustments Made \\ by Seafarers Whilst at Sea
}

\author{
Helen Devereux
}

\section{Introduction}

In this chapter some of the issues surrounding seafarers' experiences of transition, readjustment and change during a tour are presented. The voices of seafarers are heard through the inclusion of verbatim quotes from interviews conducted on board ships.

Seafarers' experiences of life at sea encompass two distinct phases: being on board a ship and being at home. As such the life of a seafarer is somewhat cyclical with change, readjustment and transition between the two phases occurring. For some seafarers this circular routine of employment-related mobility is regular with periods of time on board and at home remaining relatively consistent. These seafarers tend to be from economically developed countries. However seafarers from less economically developed countries experience sporadic employmentrelated mobility with their periods of time at sea occurring on a generally more ad hoc basis (Sampson 2013).

This chapter aims to give a flavour of a seafarer's cyclical lifestyle and considers themes regarding change and transition throughout an entire tour. These themes are discussed in chronological order moving from the start, to the middle and concluding with a consideration of the end of a tour.

It is important to note that these three concepts of start, middle and end of time into tour mean different things to each individual seafarer and as such it is not possible to quantify them. These concepts have been used as a device in order to examine seafarers' perceptions of the nature of their work and to make sense of their experiences. Bailey et al. (2007) used similar concepts of 'the beginning and end of a seafarer's time on board' to consider seafarers' perceptions of risk.

\footnotetext{
H. Devereux $(\triangle)$

Solent University, Warsash School of Maritime Science and Engineering, Southampton, UK e-mail: helen.devereux@solent.ac.uk
} 
In order to appreciate the somewhat unique aspects seafarers experience in relation to change, readjustment and transition throughout a tour it is firstly important to understand some of the peculiarities of being a seafarer.

\section{Life as a Seafarer}

One such peculiarity of life at sea relates to the number of seafarers on board a ship. Long gone are the days of hundreds of individuals employed on board a single ship, sailing from their home port around the world for vast periods of time before returning to their home port and 'paying off' with the wages they have earned.

In today's seafaring industry the number of seafarers on board can vary with the number of seafarers decided by the vessel's flag state in accordance with safe manning regulations (ILO 2006). Winchester et al. (2006) state the average crew size of dry cargo vessels to be between ten and twenty-five people (depending on various factors including ship size). On board a single ship there are likely to be crew members of numerous nationalities, all of whom are subject to different pay scales. Furthermore, the length of time a seafarer spends on board a ship per assignment is subject not only to the type of ship they are sailing on but also to factors such as rank, nationality and which crewing agency recruited them. It is not uncommon to find two seafarers on board the same ship, working at the same rank but having completely different tour lengths. As one seafarer described:

There's a Polish guy and a Croatian. The Croatian he has I think 3 months and the Polish I don't remember but they have a much longer contract than we have Second Officer.

To give a further example, Oldenburg et al. (2009) found the average contract duration for Europeans to be between three and six months and for non-Europeans between six and nine months.

Inevitably, the differences in tour lengths between seafarers working on board the same ship can lead to issues which can include resentment as well as a lack of understanding of the amount of time some individuals spend on board in comparison to those from more economically developed countries.

Perhaps the main reason why differences in terms of employment for seafarers exist is the issue of widespread precarious employment prevailing throughout the seafaring industry. Bloor and Sampson (2009, p. 713) explain:

[...] contractual arrangements for outsourced labour vary between ship operators and between ship sectors (ferry, cruise, bulk carriers, container ships, oil tankers, gas carriers, etc.) but typically only senior officers will be employed on permanent contracts if permanent contracts are in place at all: junior officers (frequently) and crew (almost invariably) will be employed on short-term contracts of a year or less, but will remain 'on the books' of the crewing agency.

It is necessary to understand how issues regarding precarious employment relate to a seafarer's familiarity with both their workplace and their colleagues in order to appreciate the concept of transition, readjustment and change throughout a tour. 
Therefore, in terms of familiarity with colleagues and their vessel seafarers can be broadly categorized into the following three categories:

1. Seafarers who return to the same vessel and work alongside familiar colleagues.

2. Seafarers who return to the same vessel and work alongside unfamiliar colleagues.

3. Seafarers who join an unfamiliar vessel and work alongside unfamiliar colleagues.

A seafarer who returns to the same vessel for subsequent tours is generally employed on a back-to-back schedule. 'Back-to-back' is a term used to describe a situation where an individual is 'paired' with another seafarer of the same rank. These two individuals return to the same vessel for consecutive tours, with one individual on leave whilst the other is on board and as such the position on board is consistently filled by these two seafarers. These seafarers tend to be senior officers from more developed countries and the back-to-back working arrangement facilitates a number of advantages when compared to other seafarers' working schedules. Back-to-back seafarers enjoy greater flexibility regarding when they join and leave the vessel, and they are to some extent able to determine their tour length. This is because back-to-back seafarers tend to arrange relieving each other between themselves with little input from shore side manning. As one explained:

I could just email [seafarer's name] and say can you join now and he would just say yes or no and then that's how we do it. We arrange our reliefs and then I just go and see the captain and say [seafarer's name] is coming this port (Second Engineer).

Other seafarers however are granted little, if any, flexibility regarding when they join the vessel. For some seafarers the notice they are given prior to joining is particularly short. One complained that:

They [crewing department of shipping company] tried 12 hours once and I said no way Able Seaman $(A B)$.

The AB's comment gives rise to an interesting issue as it suggests that some seafarers may begin a tour with little or no time to begin to process the transition between life at home and life at sea.

\section{The Beginning of a Tour}

The idea of transition between life at home and life on board suggests that a seafarer's use of time immediately prior to joining a ship is of particular interest. In addition, the change, readjustment and transition is further complicated by the fact that not all seafarers travel directly from home to the ship. Some seafarers, particularly those from developing countries, first attend a manning agency to complete paperwork and other formalities prior to joining. This situation exists in the Philippines whereby a seafarer must travel to Manila, regardless of the distance from their 
home prior to joining a vessel. Other seafarers attend International Convention on Standards of Certification and Watchkeeping (STCW) or company training immediately before going to a ship. In addition some seafarers may transfer from one ship directly to another according to company requirements.

Even when travelling directly from home a seafarer may travel for a considerable period of time in order to reach a ship. The journey may involve any number of connecting flights and then numerous hours travelling in a helicopter or taxi before arriving at the ship. The following example is illustrative:

We usually take the [Swedish term] flight in the morning, 6 o'clock in the morning from the airport, you arrive at the ship, if you go to Pembroke you arrive at the ship 3 o'clock in the afternoon and then you have your reliever standing there and he want to go also (Chief Engineer).

This increasingly international nature of joining a ship means that many seafarers arrive at a vessel weary from travel and jet lagged, a result of the time zones crossed during the journey. Cleary this is not an ideal situation as jet lag can cause effects such as difficulties with sleeping and decreased performance (Waterhouse et al. 2007). These effects are likely to hinder a seafarer's ability to transition to life on board at the early stage of time into tour.

To put this issue into perspective Wadsworth et al. (2006) utilized questionnaires and identified that $66 \%$ of respondents had no opportunity to sleep between travelling to a ship and beginning their first work shift. Of particular concern is the fact that $47 \%$ of this group had travelled in excess of six hours and $19 \%$ had travelled for 12 hours or more (Wadsworth et al. 2006).

In addition to tiredness from travelling, seafarers may well be joining a vessel they are completely unfamiliar with and sailing with colleagues they have not met previously. For some seafarers, particularly those with little experience of the lifestyle, it can be somewhat overwhelming. One told me that:

The first week I don't know my way around, I don't know the people, I'm jet lagged, I'm tired, I hate it, I want to go home, I want to cry, it's just the worst experience ever (Deck Cadet).

Furthermore, even with experience of life at sea, a lack of familiarity with their vessel can cause additional stresses to individuals. One seafarer described how:

I haven't even done any bridge equipment familiarization yet. I mean cos tomorrow morning I'm going to get a pilotage on the way out, you know I might have to set up the bridge and of course I can't do the AIS or any of that shit yet because I haven't even been shown it, different radar systems, different ECDIS systems (Third Officer).

The issues regarding familiarity are not so apparent for those seafarers working a back-to-back schedule however the process of readjusting to the generality of sea-life can still be challenging as a bosun stated:

You're just getting back into it, you've had 5 weeks off of possibly doing nothing, playing golf, getting drunk and then you're back to no alcohol, no free time as such and that's it so you're well, I would liken it to prison but it's not, you've gone from being able to do anything you want to this is what you've got to do so yeah probably say 3 or 4 days to a week to sort of get into it (Bosun). 
Readjusting to life on board can take different seafarers different periods of time. Therefore to appreciate the concept of the beginning of a tour it is important to understand that the seafarers interviewed suggested the beginning was until they felt settled on board with any time after this being considered either the middle or the end of the tour.

\section{The Middle of a Tour}

Regardless of when within a tour they are, seafarers work fixed routines whilst at sea and in port and these routines last for the entire duration of their time on board. As such, daily life at sea has a rhythm as regular as clockwork, marked by recurring events such as meal times and watch changes (Knudsen 2009). For some seafarers the routine can be an issue, particularly during the middle of a tour when they look back at the length of time they have already followed the routine for and also look forward to how much longer they must continue to do so. One explained how:

The middle of the trip is quite tough because you are feeling little bit tired, the routine you know like the well every day's the same, every day you are eating on the same time, every day you are starting the day from the same things (First Officer).

This mid-tour feeling of monotony could be compared to workers in shore-based occupations who work a traditional pattern of Monday to Friday and refer to Wednesday as 'hump day', meaning 'the middle of a work week; used in the context of climbing a proverbial hill' (Urban dictionary 2019) [online].

Unlike workers in shore-based occupations however seafarers experience a lack of traditional temporal markers such as weekends. For this reason seafarers devise concepts to observe the passage of time spent on board. One described how:

I start counting down, I work on ports I might say I've got 3 ports to go, 2 ports to go, 1 port to go, if it's a long trip then. No say 3 weeks, I'm counting down now I'm thinking I've only got 3 weeks (Deck Cadet).

There is however an interesting variation regarding the routine of life on board between officers and ratings. The routine of ratings on board is controlled by the officers and generally, tasks are set each day by those seafarers sailing in management positions. The tasks are set according to the planned maintenance system and prevailing weather conditions. In contrast those in management positions plan their own work day and many reported doing different tasks depending on how they felt. One explained that:

Sometimes you have harder day but the next day you can compensate it a little bit do different kind of work but my job you know I do different things every day I have some routine jobs but I can plan for myself (Chief Cook).

In addition to controlling the tasks carried out on board each day, senior officers also control the working hours of each individual seafarer on board. This power held 
by senior officers and lack of oversight from shore-side however is not always a positive aspect for seafarers. One suggested that:

When I was with [company name] I was doing $\operatorname{sixes}^{1}$ all the time cos we had this lazy Chief Officer (Third Officer).

In this quote the third officer illustrates how senior officers can utilize their ability to dictate the working routine of another seafarer in order to work less hours themselves. Clearly such a senior officer would be unpopular on board due to what would be seen by many as an abuse of power but there would be little the junior officers could officially do in such a situation unless they were breaking any rest hour regulation.

Working such a demanding routine of successive shifts with no days of rest in a demanding physical and psychosocial environment invariably impacts upon seafarers and for many the end of a tour is eagerly anticipated.

\section{The End of a Tour}

Inevitably, it is during the time period at the end of a tour that seafarers may begin to focus on the transition between leaving the vessel and returning home and for some seafarers this process of adjustment involves a change in working practices. One suggested that one way in which working practices change at the end of a seafarer's time into tour is a reduction in the amount of work undertaken. He said that:

I try and do as little as possible towards the end, seriously. I'd say a week before I go home or anyone goes home my opinion is you shouldn't be undertaking anything new you should just be repairing stuff and preparing for your handover (Second Engineer).

This reduction in work at the end of a tour is sometimes a pre-planned alteration in working practices as illustrated by a first officer who explained that:

I did everything ahead, looking ahead to be prepared to not leave too much work on my last days, to get proper rest before home (First Officer).

Other seafarers however suggested that whilst they worked the same number of hours the work at the end of their time into tour involved more paperwork and less manual labour than at other periods of time during their tour. In contrast some seafarers reported that they did more work at the end of their tour in order to ensure they left their responsibilities fully discharged for the person relieving them.

In addition, this process of change towards the end of a tour is further complicated by the fact that only rarely do some seafarers know the exact date on which they are going home and mandatory extensions of time on board are common. The reason for this is that for many seafarers their employment contract permits the shipping company to keep the seafarer on board for a predetermined time in addition to that

\footnotetext{
${ }^{1}$ Sixes is a common term used to refer to a shift pattern of six hours work followed by six hours rest.
} 
stated in the contract. A seafarer having to remain on board may be due to the lack of available relieving seafarers. In some countries crew members may be unable to leave the vessel due to visa requirements; such is the situation in China for British seafarers. Additionally, the vessel may be sailing on a long ocean passage and the next port of call may be a number of weeks' away.

In some shipping companies managers are reluctant to let seafarers leave the vessel in expensive countries and try to minimize repatriation costs by waiting for the vessel to call at cheaper ports. Repatriation costs can be further reduced by only allowing seafarers to be repatriated in small groups and some seafarers may then be required to wait until such a group can be formed. These mandatory tour extensions can impact upon a seafarer's transition, readjustment and change. One described how:

When you came and you know you need to do 6 weeks it's you know you prepare yourself looking for the calendar, that okay end of the month you will be at home yeah but other things you are coming and middle of the month you will be at home and then someone is telling you you need to stay longer. Then you are not thinking about the job you are thinking only to finish your trip and not that the job needs to be done. Of course you are doing everything but the way of the thinking has changed rapidly (First Officer).

In some circumstances mandatory tour extensions can therefore be a cause of additional anxiety and worry for seafarers who are anticipating returning home and impact upon the transition process. It is important to consider that there are few other industries whereby it is compulsory for workers to remain at work for weeks or even months longer than they anticipated.

\section{Conclusion}

This chapter has illustrated how the transition, change and readjustment process which seafarers experience is a complex process and not one which can be quantified. Seafarers' lives are characterized by different temporal rhythms and two locations, one being home and the other being a ship. Whilst parallels can be drawn with other occupations which require an individual's intermittent absence from home the transition, readjustment and change process undergone by seafarers is somewhat unique. The transition process varies at different points within a tour, with an early stage and a late stage of a tour proving to be the most demanding for many seafarers.

Upon joining a vessel readjustment must occur quickly and in many cases alongside recovery from long distance travelling and jet lag. It is also important to acknowledge that many seafarers do not know when they will be returning home, an issue which affects not only themselves but also those individuals who are waiting at home for the seafarer to return. 


\section{References}

Bailey, N., N. Ellis, and H. Sampson. 2007. Perceptions of Risk in the Maritime Industry: Personal Injury. Seafarers International Research Centre (SIRC), Cardiff University.

Bloor, M., and H. Sampson. 2009. Regulatory Enforcement of Labour Standards in an Outsourcing Globalized Industry the Case of the Shipping Industry. Work, Employment \& Society 23 (4): 711-726.

ILO. 2006. Maritime Labour Convention [Accessed on 23rd November 2019]. Available at http:// www.ilo.org/wcmsp5/groups/public/@ed_norm/@normes/documents/normativeinstrument/ wcms_090250.pdf.

Knudsen, F. 2009. Paperwork at the Service of Safety? Workers' Reluctance Against Written Procedures Exemplified by the Concept of 'Seamanship'. Safety Science 47 (2): 295-303.

Oldenburg, M., H.J. Jensen, U. Latza, and X. Baur. 2009. Seafaring Stressors Aboard Merchant and Passenger Ships. International Journal of Public Health 54 (2): 96-105.

Sampson, H. 2013. International Seafarers and Transnationalism in the Twenty-first Century. Manchester: Manchester University Press.

Urban dictionary. 2019. Hump Day. http://www.urbandictionary.com/define.php?term=hump+day [Accessed on 23rd November 2019].

Wadsworth, E.J., P.H. Allen, B.T. Wellens, R.L. McNamara, and A.P. Smith. 2006. Patterns of Fatigue Among Seafarers During a Tour of Duty. American Journal of Industrial Medicine 49 (10): 836-844.

Waterhouse, J., T. Reilly, G. Atkinson, and B. Edwards. 2007. Jet Lag: Trends and Coping Strategies. The Lancet 369 (9567): 1117-1112.

Winchester, N., H.A. Sampson, and T. Shelly. 2006. An Analysis of Crewing Levels: Findings from the SIRC Global Labour Market Study. Seafarers International Research Centre (SIRC), Cardiff University.

Open Access This chapter is licensed under the terms of the Creative Commons Attribution 4.0 International License (http://creativecommons.org/licenses/by/4.0/), which permits use, sharing, adaptation, distribution and reproduction in any medium or format, as long as you give appropriate credit to the original author(s) and the source, provide a link to the Creative Commons licence and indicate if changes were made.

The images or other third party material in this chapter are included in the chapter's Creative Commons licence, unless indicated otherwise in a credit line to the material. If material is not included in the chapter's Creative Commons licence and your intended use is not permitted by statutory regulation or exceeds the permitted use, you will need to obtain permission directly from the copyright holder.

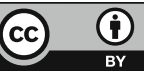

